\title{
Comparison of Elasmobranch Catches from Research Trawl Surveys and Commercial Landings at Port of Viareggio, Italy, in the Last Decade
}

\author{
A. J. Abella and F. Serena \\ Agenzia Regionale per la Protezione Ambientale della Toscana \\ Via Marradi 114, 57100 - Livorno Italy
}

\begin{abstract}
Abella, A. J., and F. Serena. 2005. Comparison of Elasmobranch Catches from Research Trawl Surveys and Commercial Landings at Port of Viareggio, Italy, in the Last Decade. J. Northw. Atl. Fish. Sci., 35: 345-356. doi:10.2960/J.v35.m526
\end{abstract}

\begin{abstract}
A program to monitor commercial elasmobranchs was put into effect at Viareggio, the most important fishing port of the Tyrrhenian and Ligurian seas. Size structure of the catches and spatial information on fishing effort distribution were collected monthly by species and gear over the period 1990-2001. Data on catch rates and geographical distribution were also obtained from annual research trawl surveys during 1985-2001 in the same area that the fish landed at Viareggio were caught. The distribution of the fishing effort for every major fishery was compared with catch rates of research trawl surveys for the more important elasmobranch species; two batoids, Raja asterias and Raja clavata and two sharks, Scyliorhinus canicula and Galeus melastomus. Trends in catch rates derived from fishery independent and fishery dependent sources appear inconsistent. This is probably due to spatial shifts in the effort allocation of the fisheries as a consequence of changes in target species that occurred during the analysed period. The current level of fishing pressure and fishing pattern, that remained almost unchanged for the last 10 years, seems sustainable for each one of the four species studied. This may be related to a relatively low fishing pressure on some grounds where certain species are concentrated, to the discarding of a portion of the individuals caught as well as to life history characteristics of some species that make them less sensitive to increased fishing mortality.
\end{abstract}

Key words: catch, distribution, effort, landings, rays, research surveys, shark

\section{Introduction}

Within the marine ecosystem, elasmobranchs play an important role at or near the top of the food web. In commercially exploited ecosystems, however, their life history characteristics make them particularly vulnerable to fishing pressure. Their susceptibility to overfishing has been noted by many authors (Stevens et al., 2000; Musick et al., 2000). There is some evidence to suggest that these vulnerabilities apply for Squalus sp., Mustelus spp. and Squatina sp. in the Northern Tyrrhenian-Ligurian Sea (Vacchi et al., 2000), even though quantitative information (such as long data series of captures) there is incomplete.

Since 1990, a monitoring program has been in place, aimed at the collection of data from commercial landings of chondrichthyan and teleost fish in the main fishing harbours of the area of our study. Additionally, research trawl surveys utilizing a traditional Italian trawl net have also been performed each year since 1985 . The research surveys cover the whole area where the commercial fleets operate, which enables changes in catch rates to be monitored with time. Moreover, this permits an analysis of the spatial aspects of both the fishery and the distribution of resources. In this study spatial aspects are compared and considered in terms which are likely to have some influence on the abundance and stock status of the main species of elasmobranchs in the area.

\section{Materials and Methods}

Data from two sources were used: samples of commercial landings, carried out on a monthly basis from 1990 to 2001 at Viareggio, the major port for fisheries of the Northern Tyrrhenian-Ligurian Sea, and 27 research trawl surveys carried out in the same area and in different seasons between 1985 and 2001. Trawl surveys were performed with a random allocation of hauls stratified by depth. Tows lasted 1 hour and were done at a towing speed of 3.5 knots and exclusively during the day. Catch of each tow was sorted by species, and weights and numbers recorded. Information on individual size and weight, sex, maturity, was taken for a selected species, including those considered in this study. For more details on surveys sampling design see Relini and Piccinetti (1996).

The analyses of fishery data pertained to species composition, number of vessels, utilized gear type, date and fishing area. Information derived from direct interviews 
during the landing operations comprised number of tows per day, amount of catch by species and vessel characteristics. The spatial information associated with the fisheries as well as that derived from research trawl surveys on distribution of species abundance were analysed with ArcView GIS (ESRI, 1996). The geographical distribution of fishing effort by fishing strategy was represented and analysed by using the application MLFD (Mapper of Landed Fish Data) (Fortunati et al., 2001). Maps that display the effort distribution pattern by fishing gear and the distribution of catch rates for the main commercial species produced during a previous study (Abella et al., 2001) were used in order to compare the spatial distributions of fleet and resources.

Four species were selected for study because of their major abundance and commercial interest: the two sharks, the blackmouth catshark (Galeus melastomus) and the small-spotted catshark (Scyliorhinus canicula), and the two batoids, the thornback ray (Raja clavata) and the starry ray (Raja asterias).

\section{Results}

Catch composition of the research survey tows included 208 species of finfish, of which chondrichthyans represent 13\% (11 sharks, one chimaera and 14 batoids). Catch composition of surveys, however, is affected not only by the abundance of the species, but also by the suitability of the fishing gear to capture each species. The number of species observed in the commercial landings was smaller, with 105 species of finfish. This fact is also reflected by the number of elasmobranch species caught, with only 16 species (6 sharks and 10 batoids), which represents about $15 \%$ of the total fish species landed.

Operational areas of vessels utilizing beam trawls and bottom trawls in general overlap, but species composition of the catch may be quite different. $R$. asterias is generally the most common species caught with beam trawls but is negligible in bottom trawls. Figure 1 shows the relative importance of the most common species in the landings of the beam trawl fishery atViareggio. The method of Biseau (1998) was used as an objective criterion for the identification of the species more representative of the fishery. Even if fishers do not declare this ray as a target of the fishery traditionally directing for flat fishes, in particular Solea vulgaris, the absence of $R$. asterias in the catch would make the beam trawl fishery in the area unprofitable. On the other hand, catches of starry ray obtained with the bottom trawl are relatively modest.

Figure 2 shows the geographical distribution of the 4 elasmobranch species derived from research trawl data with relative abundance expressed as catch per hour towed. There is a clear spatial shift in the distribution of the species. $R$. asterias is situated relatively close to the coast, with a higher relative abundance on the Italian and Corsica continental shelves, in the depth interval 0-150 m (Baino and Serena, 2000). A higher abundance of individuals was observed near the Corsica coast where fishing pressure is lower. Only a few trawlers operate from

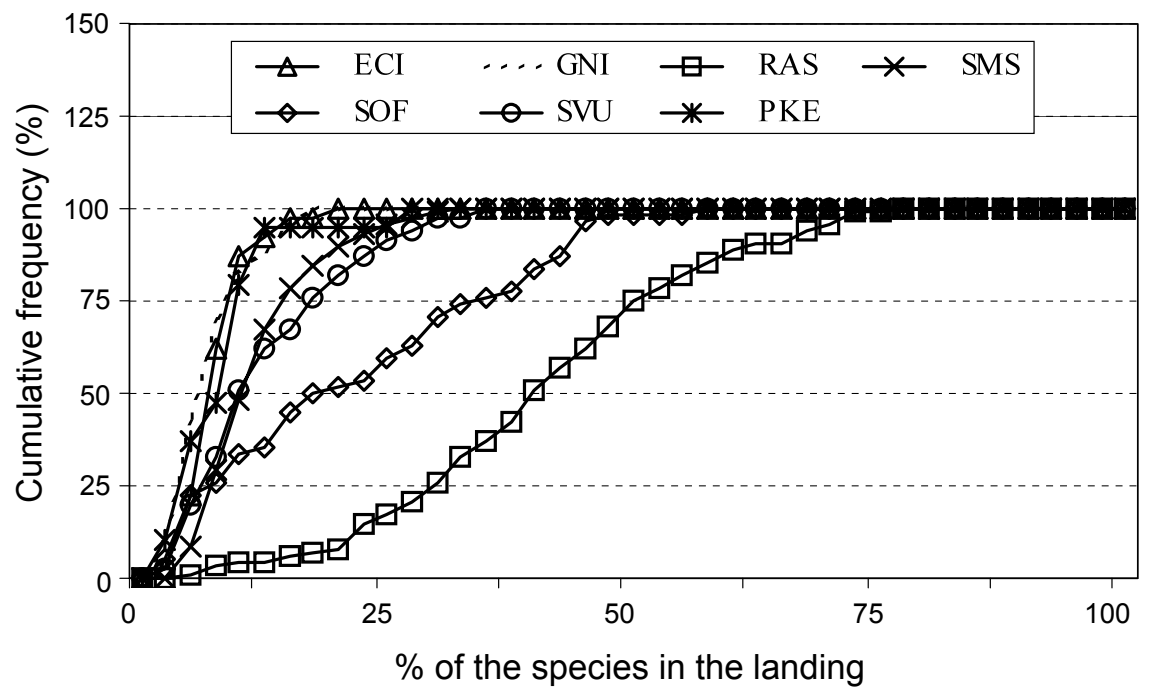

Fig. 1. Percentage of a selected number of species in the landing of each single trip using a variant of beam trawl vs. cumulative frequency (\%). ECI (Eledone cirrhosa), GNI (Gobius niger), RAS (Raja asterias), SMS (Squilla mantis), SOF (Sepia officinalis), SVU (Solea vulgaris), PKE (Penaeus kerathurus). 

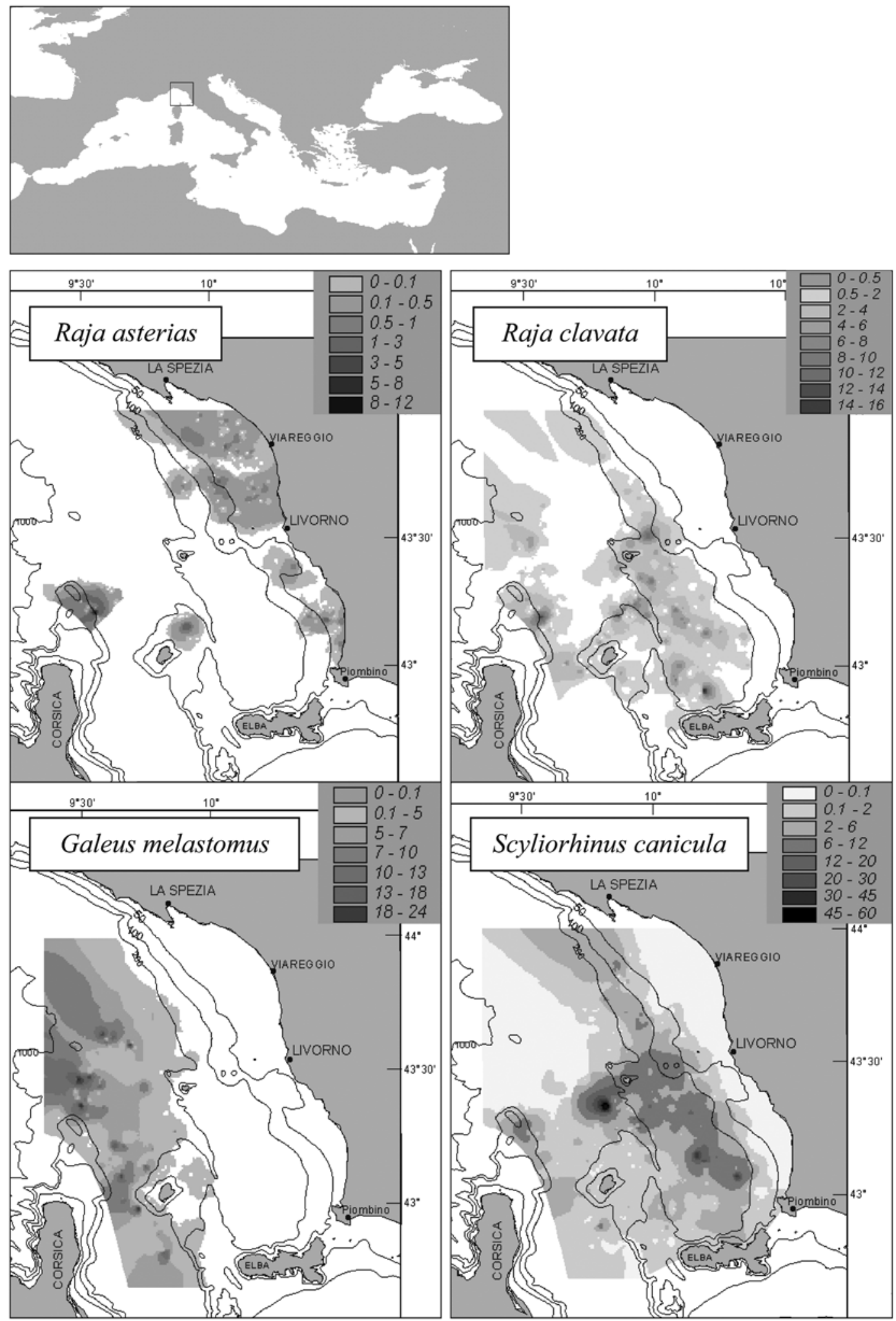

Fig. 2. Distribution of the relative abundance ( $\mathrm{kg} / \mathrm{hr}$ towing) for the 4 studied species derived from trawlsurveys data. 
the Corsica harbours, while Italian vessels exert a modest fishing pressure in this area (ARPAT, unpublished data).

Aggregated trawl survey data related to the relative abundance of the species in the study area for the period 1985-2001 are represented in Fig. 2. Aggregated information allowed a better representation of the distribution of the single species, considering the low quantities that in general are caught. Scyliorhinus canicula and R. clavata share the same grounds and are mainly concentrated in the depth interval $100-250 \mathrm{~m}$, while G. melastomus is a bathial species, and is mainly concentrated between 400 and $800 \mathrm{~m}$ of depth (Baino and Serena, 2000).

Figure 3 shows the current distribution of fishing effort of the Viareggio fleet. There are no such detailed charts of the fishing effort distribution of the other fleets that operate in the area, as those fleets are based in Livorno and Piombino.

Table 1 shows the number of vessels by fishing gear for each port in the studied area. Table 2 shows the commercial landings in the Viareggio harbour by gear during year 2001, while Table 3 lists the mean catch composition of trawl surveys for the period 1990-2001. Finally, Table 4 includes the main available biological information regarding the 4 species in the area studied.

A reduced number of trawlers belonging to the $\mathrm{La}$ Spezia fleet operate on the same grounds northwards to Viareggio harbour. Moreover, some small boats utilizing trammel nets capture modest quantities of $R$. asterias close to the coast. The Livorno fleet is also relatively small. Trawlers concentrate its effort mainly on the grounds south to $43^{\circ} 30^{\prime}$ at depths between 100 and $400 \mathrm{~m}$ and hence there is little overlap with the operational areas of the Viareggio fleet. Raja clavata and S. canicula are particularly abundant in these grounds exploited by the Livorno fisheries and they are the more important landed elasmobranch species. The Piombino fleet is quite small and its fishing effort is evenly distributed towards the north and the south of the mentioned port. Most of their vessels use gear aimed at the capture of small pelagic species and hence without any direct influence on the abundance of the studied species.

No clear trends were found in relative abundance for the 4 species studied in the area derived from research surveys due to the high variability among years and the relatively short time series (Fig. 4). No data are shown for 1989-90 because trawl surveys coverage made results related to these years unreliable. An increase in abundance may have been occurring in the last years for $R$. clavata, S. canicula and G. melastomus. Landings data, with abun- dance indices expressed as catch in kg per hour, suggest a decreasing trend in all the species (Fig. 5). This seems
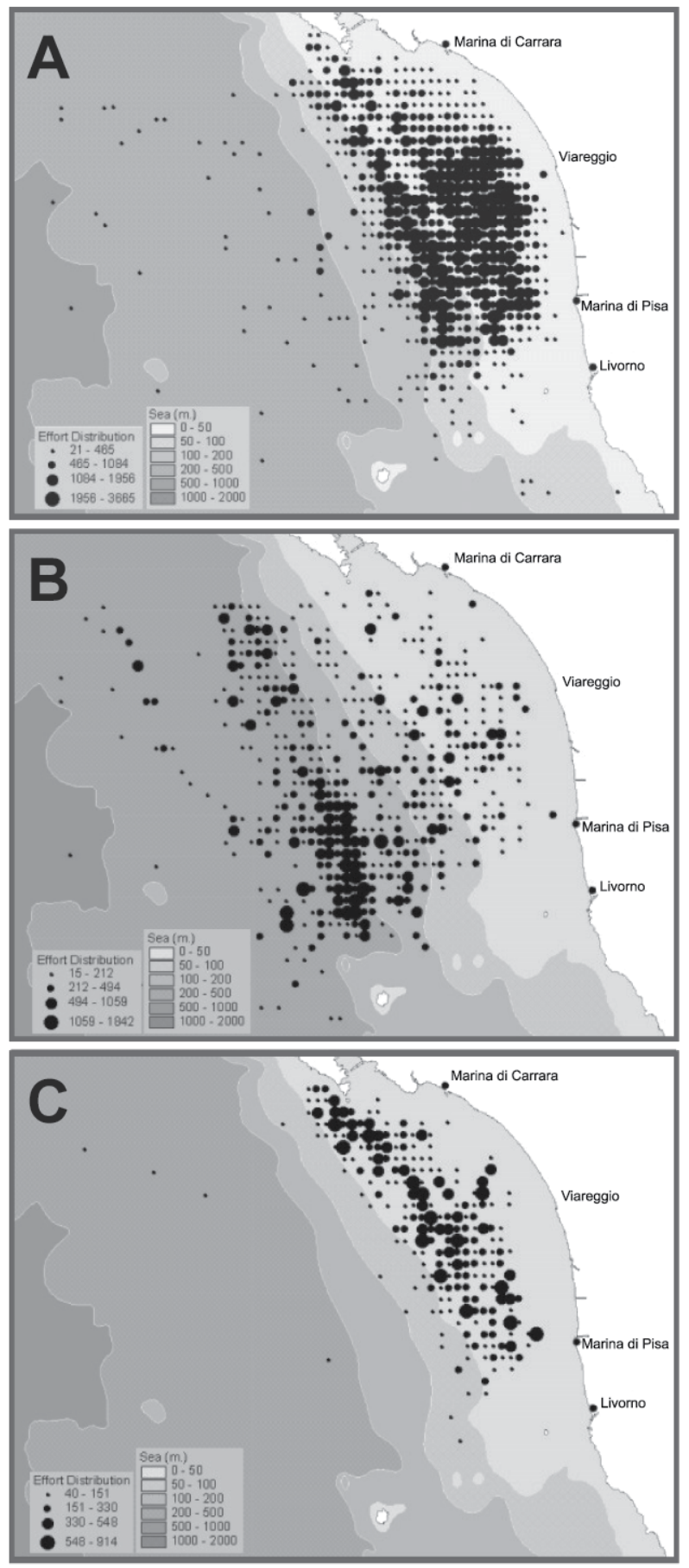

Fig. 3. Distribution of fishing effort of the Viareggio fleet (number of tows performed inside each square of a $1 \times 1$ nautical miles grid): (A) utilizing a variant of the Italian bottom trawl (volantina), (B) utilizing the traditional Italian bottom trawl (tartana), and (C) utilizing a variant of the beam trawl (rapido). 
TABLE 1. Number of vessels targeting bethic-demersal species divided by fishing typology, operating in the main ports of the studied area.

\begin{tabular}{lccc}
\hline \hline & $\begin{array}{c}\text { Small scale } \\
\text { fisheries }\end{array}$ & $\begin{array}{c}\text { Bottom } \\
\text { trawlers }\end{array}$ & $\begin{array}{c}\text { Rapido } \\
\text { (beam trawls) }\end{array}$ \\
\hline Marina di Carrara & 30 & 1 & \\
Viareggio & 77 & 78 & 2 \\
Forte dei Marmi & 181 & & \\
Livorno & 111 & 30 & \\
Piombino & 37 & 9 & \\
Marina di Pisa & 10 & 3 & \\
Vada & 22 & 1 & \\
Marina di Cecina & 18 & 2 & \\
Castiglioncello & 28 & 1 & \\
Isola di Capraia & 5 & & \\
Mariana Marina & 16 & & \\
\hline
\end{tabular}

particularly evident during the last 3 years. However, the performance of any robust statistical analysis of the time series was impossible due to the above mentioned shortage of data series and observed variability. A fitting of polynomial functions with relative equation and goodness of fit is included in the graphs.

A significant portion of the species in this study is discarded at sea. This is particularly the case for $G$. melastomus. Only a fraction of the bigger individuals of the species (length $>40 \mathrm{~cm}$ ) is landed, and exclusively at Viareggio. The degree of discarding is dependent on the limited market demand of this species. In the case of $S$. canicula, a commercially valuable species, only the individuals smaller than $36 \mathrm{~cm}$ are discarded. While almost all the individuals of $R$. clavata smaller than 38 $\mathrm{cm}$ of total length are discarded at sea, most of the small individuals of $R$. asterias caught near shore with trammel and gill nets by the artisanal fisheries of Viareggio are landed. Small-scale fisheries target soles (Solea spp.) and other flatfish.

Juveniles of starry rays are concentrated very close to the coast (2-15 m depth) and hence not available for trawling.

Figure 6 shows that almost all the immature individuals of the two sharks are discarded while for $R$. clavata some immature individuals, with total length between 35 and $40 \mathrm{~cm}$ are landed. The small-scale fishery of Viareggio, as stated before, lands an important number of juveniles of $R$. asterias. The size distribution in the catches, the fraction discarded and the size of first maturity $\left(L_{m}\right)$ (data derived from literature and included in Table 4) for the 4 species studied are shown.

\section{Discussion}

Fewer species observed in the commercial landings compared to what is observed in the catch of scientific hauls was initially considered to be inconsistent. The explanation of this phenomenon is linked to the utilization by the Viareggio fleet of different gears and strategies, each more or less suitable for the capture of a wide spectrum of species. With such a variety of fishing techniques, a greater number of species in the catch would be expected. However, diversity of commercial landings is drastically reduced due to the discard at sea of many species with no commercial value (e.g. Etmopterus spinax, Chimaera monstrosa) and of undersized individuals of commercially valuable species.

Commercial catch rates of elasmobranch species are usually higher than those obtained through the randomly distributed scientific hauls utilizing the bottom trawl net. This is mainly due to the use in commercial fishing of specific and more suitable gears, but also because fishing activity is concentrated where some species are more abundant. An example is the capture of $R$. asterias with beam trawls (rapido), characterised by high catch rates.

The four species in this study appear quite resilient to fishing pressure if compared with other elasmobranchs. Most are caught with bottom trawl nets as a by-catch in fisheries targeting different assemblages of teleost fish. These gears are not very suitable for the capture of flat fishes such as rays. For instance, landings of $R$. asterias from the bottom trawl net fishery are negligible, even if the species is quite common on the grounds where the bottom trawl fleet operates. At Viareggio, the species is mainly caught on the same grounds with the "rapido" beam-trawl. The rapido is, however, utilized only by a limited number of fishing vessels. The species constitutes the main component in weight of the species assemblages caught with this gear and annual catches mainly composed of adults are about 14 tons. The starry ray is also caught with trammel nets and gillnets in the small-scale fisheries, with a mean annual catch of about 6 tons, composed almost exclusively by juveniles. While the two rays and $S$. canicula commercial price may be fairly acceptable and individuals of these species (mainly adults) are stored and landed, G. melastomus has a very low commercial value. The latter species is an important component of the by-catch of the Nephrops norvegicus fishery. Most of the time, all the individuals of this species are discarded, or in some cases, depending on market demand, a limited quantity of big-sized individuals is landed. The current total annual landings of blackmouth catshark are about $700 \mathrm{~kg}$ was recorded in 2002. 
TABLE 2. List of recorded species and amount of landings at the Viareggio harbour by gear (Tartana, Volantina and Rapido) in year 2000.

\begin{tabular}{lclc}
\hline \hline Species & Tons/year & Species & Tons/year \\
\hline & \multicolumn{3}{c}{ Tartana } \\
Nephrops norvegicus & 29.3 & Raja clavata & \\
Micromesistius poutassou & 22.1 & Lophius budegassa & 1.4 \\
Physics blennoides & 9.0 & Illex coindettii & 1.1 \\
Merluccius merluccius & 6.0 & Gobius niger & 0.9 \\
Eledone cirrhosa & 5.0 & Mullus barbatus & 0.8 \\
Lepidopus caudatus & 4.3 & Argentina sphyraena & 0.8 \\
Parapenaeus longirostris & 3.6 & Trigla lucerna & 0.8 \\
Lepidorhombus boscii & 3.3 & Trisopterus minutus & 0.8 \\
Helicolenus dactylopterus & 3.1 & Loligo forbesi & 0.6 \\
Squilla mantis & 2.9 & Zeus faber & 0.6 \\
Todaropsis eblanae & 2.7 & Trigla lyra & 0.5 \\
Trachurus trachurus & 2.6 & Penaeus kerathurus & 0.5 \\
Chlorophthalmus agassizii & 2.6 & Pagellus bogaraveo & 0.4 \\
Galeus melastomus & 2.4 & Todarodes sagittatus & 0.4 \\
Sepietta oweniana & 2.4 & Scyliorhynus canicula & 0.4 \\
Pasiphaea sp. & 1.7 & Trachurus mediterraneus & 0.4 \\
Conger conger & 1.7 & Loligo vulgaris & 0.3 \\
Lophius piscatorius & 1.7 & Mullus surmuletus & 0.3 \\
Sepia officinalis & 1.6 & Raja asterias & 0.3 \\
Centrolophus niger & 1.4 & Other species & 0.3 \\
------------------------------------------------------------------------------------
\end{tabular}

Squilla mantis

Mullus baratus

Nephrops norvegicus

Volantina

Gobius niger

Eledone cirrhosa

96.7

\section{Arnoglossus laterna}

3.7

96.1

Loligo vulgaris

Trachurus sp.

3.5

Sepietta oweniana

3.3

25.6

Merluccius merluccius

Sepia officinalis

epidorhombus boscii

3.2

Alloteuthis media $\quad 3.1$

Trisopterus minutus $\quad 3.1$

Micromesistius poutassou $\quad 21.5$

Lepidopus caudatus $\quad 20.8$

Penaeus kerathurus $\quad 18.4$

Conger conger $\quad 18.0$

Trigla lucerna $\quad 12.7$

Solea vulgaris $\quad 10.9$

Raja asterias

Phycis blennoides

Illex coindetti

Citharus linguatula $\quad 2.9$

Lophius piscatorius $\quad 2.9$

$\begin{array}{ll}\text { Parapenaeus longirostris } & 2.7\end{array}$

Trachinus draco $\quad 2.4$

Centrolophus niger $\quad 2.0$

Lophius budegassa $\quad 2.0$

Engraulis encrasicholus $\quad 1.9$

Todaropsis eblanaae $\quad 1.8$

Uranoscopus scaber $\quad 1.8$

Scomber scomber $\quad 1.8$

$\begin{array}{lllr}\text { Eledone moschata } & 5.3 & \text { Helicolenus dactylopterus } & 1.5 \\ \text { Octopus vulgaris } & 5.0 & \text { Raja clavata } & 1.5\end{array}$

$\begin{array}{llll}\text { Cepola rubescens } & 4.5 & \text { Boops boops } & 1.4\end{array}$

$\begin{array}{llll}\text { Trachurus mediterraneus } & 4.2 & \text { Scyliorhynus canicula } & 1.4\end{array}$

$\begin{array}{lll}\text { Pegellus erythrinus } & 3.9 & \text { Galeus melastomus }\end{array}$

Other species $\quad 14.5$

\begin{tabular}{llll} 
Raja asterias & 8.3 & Scophthalmus rhombi & 0.9 \\
Sepia officinalis & 5.0 & Arnoglossus laterna & 0.6 \\
Solea vulgaris & 4.6 & Eledone moschata & 0.4 \\
Squilla mantis & 2.3 & Gobius niger & 0.4 \\
Penaeus keraturus & 1.2 & Eledone cirrhosa & 0.3 \\
Triglas lucerna & 1.1 & Other species & 1.3 \\
\hline
\end{tabular}


TABLE 3. Mean composition of the catch of trawl surveys (years 1990-2001). Trawl surveys (mean catch per survey of about 30 hours fishing).

\begin{tabular}{|c|c|c|c|}
\hline Species & $\mathrm{kg}$ & Species & $\mathrm{kg}$ \\
\hline Merluccius merluccius & 201.5 & Lepidotrigla dieuzeidei & 11.6 \\
\hline Mullus baratus & 155.7 & Todarodes eblanae & 10.9 \\
\hline Trachurus trachurus & 99.4 & Loligo vulgaris & 10.3 \\
\hline Trachurus mediterraneus & 85.6 & Macroramphosus scolopax & 10.3 \\
\hline Micromesistius poutassou & 80.7 & Trigla lucerna & 10.1 \\
\hline Gadiculus argenteus & 79.6 & Spicara smaris & 9.9 \\
\hline Scyliorhynus canicula & 69.7 & Octopus salutii & 9.7 \\
\hline Lepidopus caudatus & 20.8 & Sepia officinalis & 8.6 \\
\hline Galeus melastomus & 57.6 & Sepietta oweniana & 8.3 \\
\hline Trisopterus minutus capelanus & 48.8 & Pagellus acarne & 8.1 \\
\hline Eledone cirrhosa & 47.5 & Scomber scombrus & 7.4 \\
\hline Lepidotrigla cavillone & 40.8 & Eledone moschata & 6.8 \\
\hline Lophius budegassa & 39.5 & Pegellus bogaraveo & 6.5 \\
\hline Engraulis encrasicholus & 37.8 & Squilla mantis & 6.2 \\
\hline Raja clavata & 37.4 & Cepola rubescens & 6.2 \\
\hline Aspitrigla cuculus & 35.8 & Mullus surmuletus & 6.0 \\
\hline Illex coindettii & 34.4 & Etmopterus spinax & 5.6 \\
\hline Nephrops norvegicus & 31.7 & Sardinella aurita & 5.5 \\
\hline Boops boops & 29.1 & Raja montagui & 5.3 \\
\hline Argentina sphyraena & 27.9 & Gobius niger & 5.3 \\
\hline Sardina sphyraena & 25.2 & Zeus faber & 5.0 \\
\hline Pagellus erythrinus & 24.8 & Sepia orbignyana & 4.9 \\
\hline Glossanodon leioglossus & 24.2 & Serranus cabrilla & 4.9 \\
\hline Octopus vulgaris & 23.8 & Parapenaeus longirostris & 4.8 \\
\hline Phycis blennoides & 22.2 & Nezumia sclerorhynchus & 4.4 \\
\hline Capros aper & 22.1 & Trigla lyra & 4.3 \\
\hline Helicolenus dastylopterus & 18.5 & Umbrina cirrosa & 4.1 \\
\hline Lepidorhombus boscii & 18.1 & Eutrigla gurnardus & 3.7 \\
\hline Lophius piscatorius & 17.8 & Raja oxyrinchus & 3.6 \\
\hline Coelorhynchus coelorhynchus & 16.4 & Aspitrigla obscura & 3.6 \\
\hline Conger conger & 14.8 & Uranoscopus scaber & 3.5 \\
\hline Chlorophthalmus agassizii & 14.3 & Bathypolypus sponsalis & 3.1 \\
\hline Alloteuthis media & 14.0 & Scorpaena scrofa & 3.0 \\
\hline Spicara flexuosa & 13.4 & Rossia macrosoma & 3.0 \\
\hline Loligo forbesi & 13.2 & Centrolophus niger & 3.0 \\
\hline Diplodus annularis & 12.6 & Raja asterias & 2.9 \\
\hline Raja miraletus & 12.4 & Other species & 80.2 \\
\hline
\end{tabular}

Small-spotted catshark and thornback ray are in general caught simultaneously in the same grounds, mainly at depths between 100 and $250 \mathrm{~m}$, on muddy bottoms characterised by the presence of a biocoenosis dominated by the crinoid Leptometra phalangium and the sea urchins Echinus spp. The mean total landings of each one of these two species in the recent years in the Viareggio harbour did not exceed one metric ton.

Figure 7 shows the frequency of activity of the fleet by depth. The fishing pressure on the grounds between the above mentioned range was progressively reduced in the ten years period 1990-99. This reduction occurred especially in the last 5 years as a consequence of recent enforcements of controls of legal size in the landings of Mediterranean hake. This resource at this depth interval is quite abundant and for a long time has been the main target of an important fraction of the Viareggio fleet. However, these grounds constitute an important nursery area of Merluccius merluccius and almost all the individuals of Mediterranean hake present there (and the individuals potentially fished) are under the legal size (Abella et al., (in press). The obligatory discard at sea of the whole catch of small Mediterranean hakes due to the impossibility to land and sell them make these grounds less profitable.

As regards to $R$. asterias, there is a clear overlapping between the main operation areas of the small fishing vessels of the Viareggio fleet and the grounds where the species is more abundant. As previously stated, the efficiency of the common fishing gear, the traditional Italian bottom trawl to capture $R$. asterias is however low. On the other hand, beam trawls capture relatively large quantities of individuals of the mentioned species 

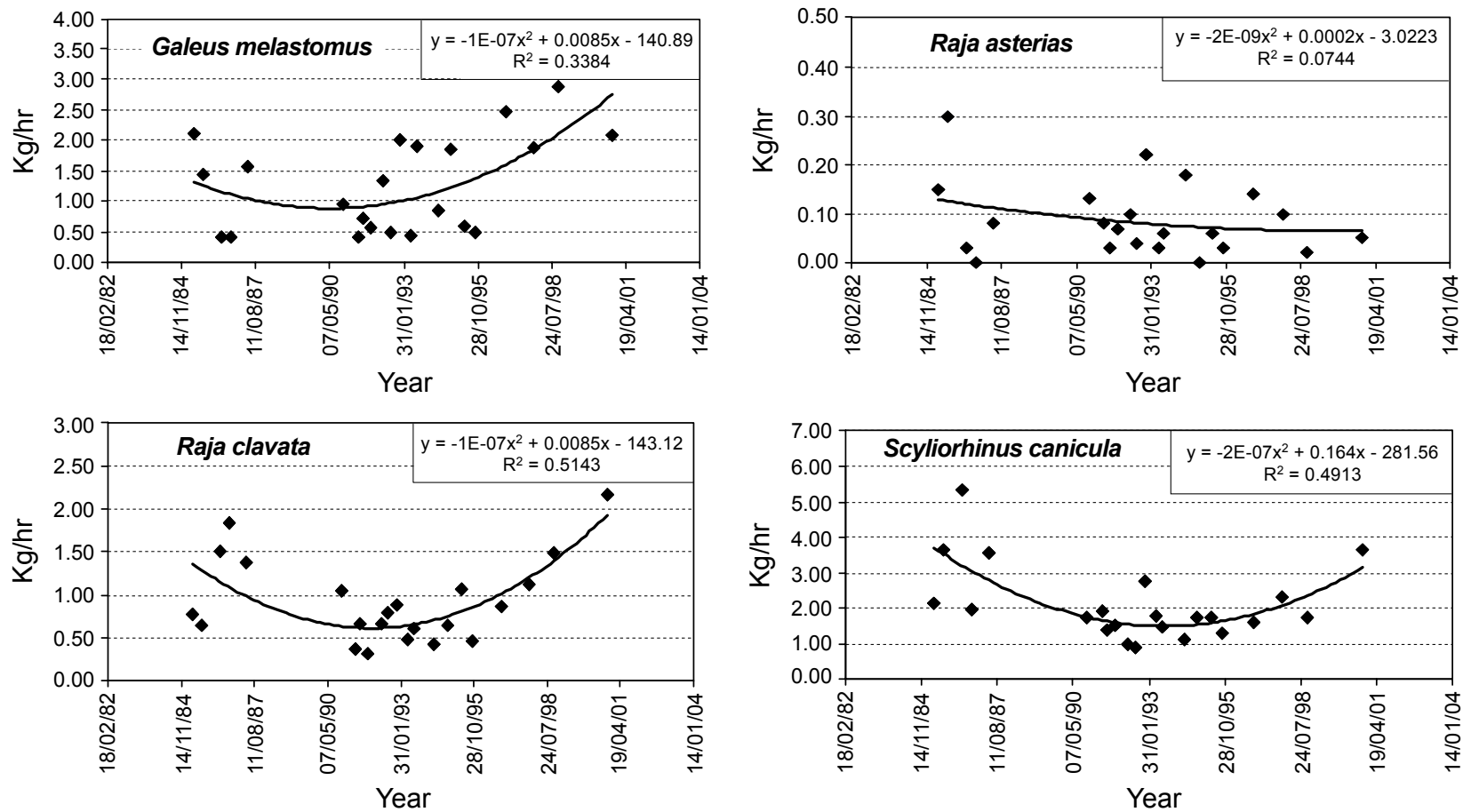

Fig. 4. Trends of relative abundance $(\mathrm{kg} / \mathrm{hr})$ for the 4 studied species derived from research trawl surveys performed between 1985 and 2001
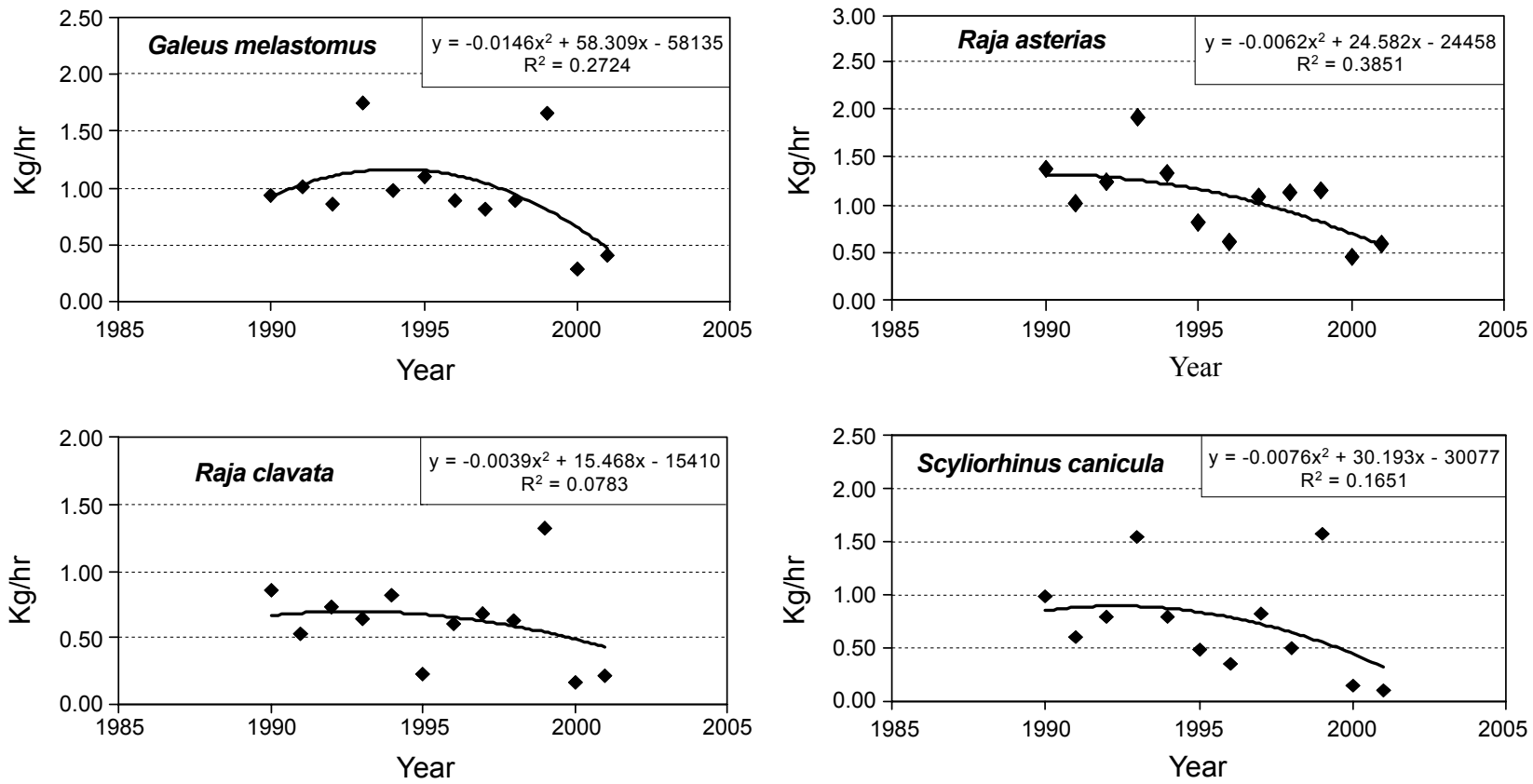

Fig. 5. Trends in catch rates (kg/hr) for G. melastomus, S. canicula, R. asterias and R. clavata for the commercial Viareggio fleet between 1990 and 2001 . 


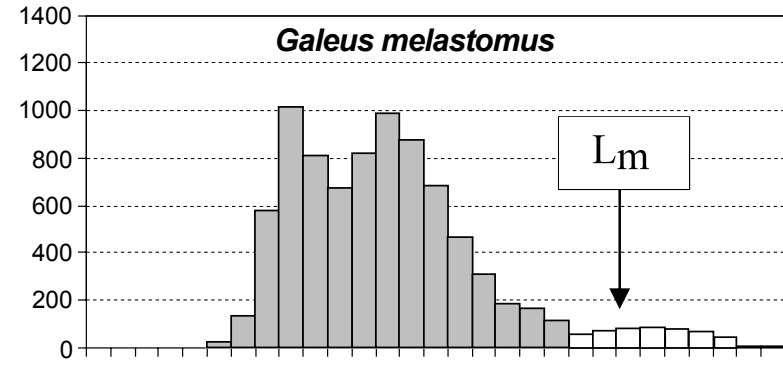

Size $(\mathrm{cm})$

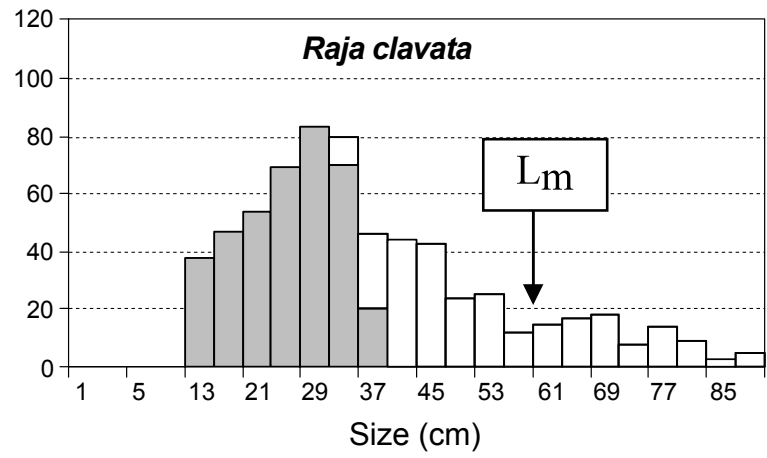

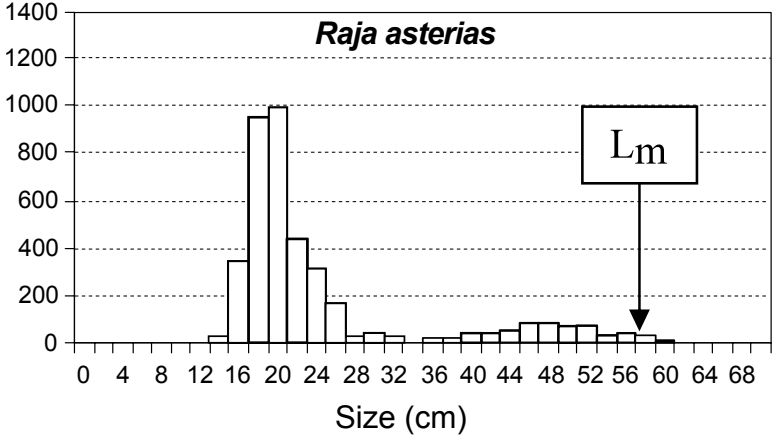

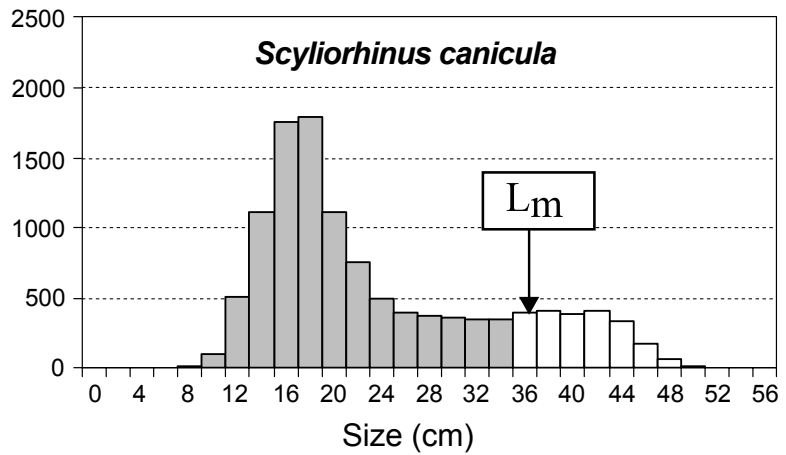

Fig. 6. Size distribution in the commercial catches of G. melastomus, S. canicula, R. asterias and R. clavata, discarded fraction (dark bars) and size at first maturity of females $\left(L_{m}\right)$.

TABLE 4. Main biological information about the 4 species studied. Sources: (1) Relini et al., 1999; (2) Cannizzaro et al., 1995; (3) Ungaro et al., 1994; (4) Fischer et al., 1987; (5) Tortonese, 1956; (6) Jardas, 1979.

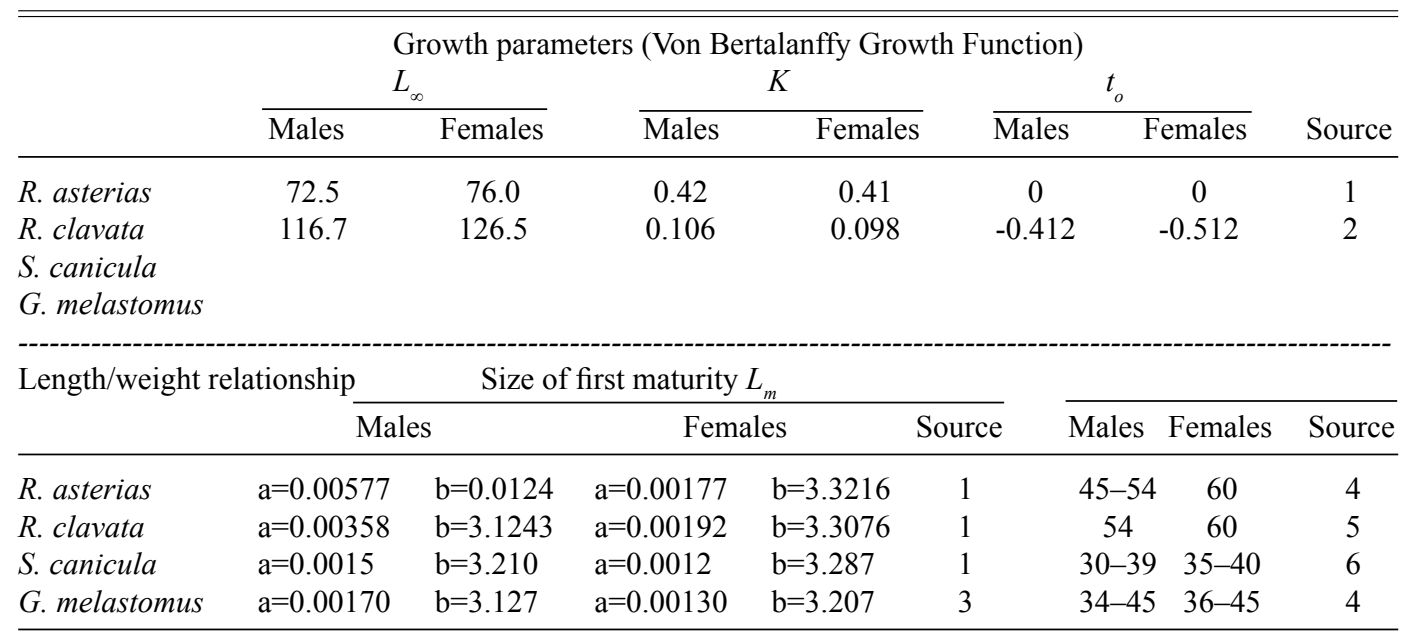

per unit of effort, but this gear is used by a very limited number of vessels as shown in Table 1 . There is however, a relatively important removal of juveniles due to the small-scale fisheries activity.
In the case of $G$. melastomus, the species is distributed in deeper waters, mainly between 250 and $800 \mathrm{~m}$. A modest number of fishing vessels of the Viareggio fleet operate on deep water grounds which target Nephrops norvegicus. 


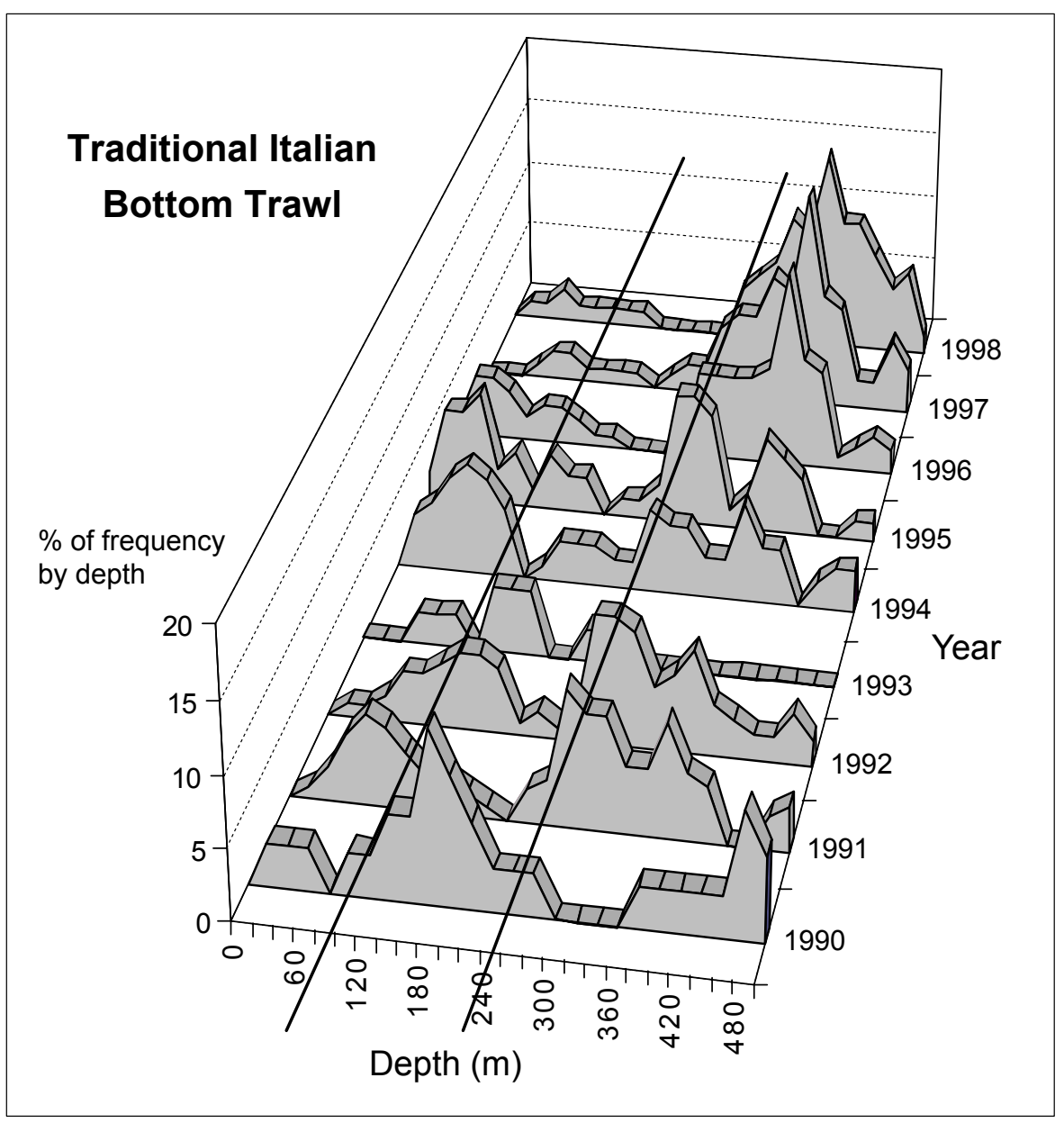

Fig. 7. Bathymetric distribution of fishing effort of the traditional Italian bottom trawl net of the Viareggio fleet, during the period 1990 to 1999 . The lines define the depth interval $100-250 \mathrm{~m}$.

The blackmouth catshark constitute an important portion of the by-catch, but most of the individuals caught, as described above, are discarded. Considering the high depth at which blackmouth catshark is caught and the observed reduced vitality of the individuals immediately after their capture, it is likely that only a small fraction of the discarded individuals of this species may survive. However, exploited Norway lobster grounds coincide only partially with the areas where G. melastomus is more abundant. In fact, as shown in Fig. 2, the higher densities of this species are found in deep waters northward of Corsica Island. In these areas the fishing pressure is quite modest and the mentioned areas could act as a refuge for these animals.

There is scarce information as regards to the probability of survival for all the studied species after they are discarded at sea. Experiments performed by the authors of this paper with individuals kept in holding tanks (data not published) have shown high rates of survival for released individuals of $R$. asterias caught with bottom trawl nets (Mancusi et al., in press). Sanchez (in press) report survival rates for released individuals of $\mathrm{S}$. canicula that are close to $100 \%$.

Research survey data do not show a decline in the abundance that can be interpreted as an index of recruitment overfishing (Baino and Serena, 2000). In fact, for the two catsharks and for $R$. clavata, an increase in catch rates is observed, while for $R$. asterias, data suggest a steady situation. These findings do not seem to be in agreement with those derived from commercial data shown in Fig. 7 , which suggests a negative trend for all the species. It is likely that the negative trends of commercial catch rates are real, even if the time series is limited. However, this trend does not necessarily have to reflect a real reduction of the abundance at sea. It is possible that they can 
be explained, at least for $S$. canicula and $R$. clavata, by the changes in the target of the fleet that have occurred recently and the above-mentioned recent minor fishing pressure on the grounds where juveniles of Mediterranean hake concentrate. These grounds geographically coincide with the more dense concentrations of $S$. canicula and $R$. clavata as shown in Fig. 2.

In the case of $S$. canicula and $R$. clavata, fishing pressure on the depth interval where they are mainly concentrated decreased in recent years (see Fig. 7). The size of the landed individuals is in general longer than the size at first maturity. Assuming a good survival rate for the discarded undersized individuals, the commercial choices allow individuals to reproduce at least once in their lives.

Regarding to $R$. asterias, the species is only partially vulnerable to the traditional bottom trawl net, and hence, their removal with this gear is very limited. Beam trawls are suitable for their capture, but only a reduced number of vessels utilise this gear in the area. Moreover, juveniles concentrate very close to the shore where trawling is forbidden. The number of small individuals caught by the artisanal fisheries is large, but it is likely to represent only a modest fraction of the standing stock of juveniles. The removal of a fraction of juveniles is in the same way compensated by the light fishing pressure exerted on adults and this should guarantee an adequate number of spawners. Moreover, a generalised reduction of the fishing effort on the grounds traditionally exploited by the Viareggio fleet occurred during the last 15 years due to a steady reduction of vessels (from 107 in 1985 to 78 in 2000).

A small fleet targeting Norway lobster operates on the grounds where G. melastomus is distributed. Most, if not all the blackmouth catshark that are caught in this fishery, are discarded at sea, generally when they are still alive.

Little is known about the life history of the 4 species in this study. Table 2 summarizes the available information for the 4 species in the Mediterranean Sea. Studies of Cannizzaro et al. (1995) suggest slow growing rates for $R$. clavata. Moreover, the species reach the age of first maturity after many years and these facts, combined with its relative low mean fecundity, reduce the chances of survival when fishing pressure is too high.

There are estimates of the growth performance of $R$. asterias. It appears to be a relatively fast growing species if compared with other rays. Recent, but partial results of tagging experiments (Mancusi et al., in press) suggest a faster growth rate for the species than that described in the literature (Serena and Abella, 1999). This fact would contribute to a more efficient and adaptive response of this species to intense exploitation. It has been stated that life-history characteristics make each species of rays and skates (but this also apply for sharks) sensitive to enhanced mortality (Walker and Hislop, 1998).

\section{Conclusion}

It appears that the 4 species studied, due to different causes, suffer relatively moderate effects from fishing pressure. The absence of evident negative trends of abundance at sea suggest that the current levels of catches and mortality by age produced by fishing activity, are sustainable and compatible with the self renewal of the studied stocks. The apparent discrepancies in the nature of the observed trends among fishery dependent and independent data can be explained, at least for $R$. clavata and $S$. canicula by a shift in the fisheries operational area (and target) that occurred in the last years. This finding demonstrates the importance of considering spatial information for the analysis of fishing effort data. The crude analysis of the trends of landings could be in this case misleading. If the fishery is directed, then a change in geographic focus could be indicative of maximizing catches, and hence might suggest local depletions could occur, whereas data from species caught only as a by-catch should be treated with great caution.

Among the 4 selected species, $R$. asterias seems to be the more highly exploited, because it is taken in a number of fisheries that remove individuals of different age-classes, including a large number of juveniles. However, it is likely that its biological characteristics and the reduced fishing pressure on the adult fraction of the stock, which experienced a further reduction in the recent years, made it more resilient to high levels of fishing activity. In fact, following the general criteria based on life history aspects to define extinction risk in marine fishes proposed by Musick (1999), this species should be included within the "medium productivity category". This is due to its early age of first maturity ( $\sim 3$ years) and a relatively short lifespan ( $\sim 10$ years $)$ even if it is characterised by a moderate fecundity.

In the case of $G$. melastomus, the fishing pressure exerted on this species, an important by-catch of the Norway lobster fishery, can be considered modest. It was estimated that total landings of blackmouth catshark in the Viareggio port are less than one metric ton. Moreover, considering its low commercial value, all the individuals 
under the size at first maturity are discarded and only a small fraction of adults are landed.

\section{References}

ABELLA, A., F. SERENA, L. FORTUNATI, U. MAMMINI, D. LARI, and R. CIARDELLI. 2001. Use of GIS for the analysis of spatial data on fishing effort and seasonal changes in fishing strategies for Tyrrhenian Sea bottom trawl fisheries. In: Proceedings of the. First International Symposium on GIS in Fishery Science. T. Nishida, C. E. Hollingworth and P. Kailola (eds.). Seattle, WA, 2-4 March 1999. Fishery GIS Research Group, Kawagoe, Saitama, Japan, p. 119-129.

ABELLA, A., F. SERENA, M. RIA. 2005. Distributional reponse to variations in abundance over spatial and temporal scales for juveniles of European hake (Merluccius merluccius) in the Western Mediterranean Sea. Fish. Res. (in press).

BAINO, R., and F. SERENA. 2000. Abundance estimation and geographical distribution of some selachians in the Northern Tyrrhenian and Southern Ligurian Seas. Biol. Mar. Medit., 7(1): 433-439.

BISEAU, A. 1998. Definition of a directed fishing effort in a mixed-species trawl fishery, and its impact on stock assessments. Aquat. Living Res., 11(3): 119-136.

CANNIZZARO, L., G. GAROFALO, D. LEVI, P. RIZZO, and S. GANCITANO. 1995. Raja clavata (L., 1758) nel Canale di Sicilia: crescita, distribuzione e abbondanza. Biol. Mar. Medit., 2(2): 257-262.

ESRI. 1996. ArcView GIS. The Geographic Information System for Everyone. Environmental Systems Research Institute, Inc., $340 \mathrm{p}$.

FISCHER, W., M.-L. BAUCHOT, and M. SCHNEIDER. 1987. Fiches FAO d'identification des espéces pour le besoins de la pêche (Révision 1). Méditerranée et mer Noire. Zone de pêche 37. 2. Vertébrés. Publication préparée par la FAO (Project GCP/INT/422/EEC). Rome, FAO, pp. 761-1530.

FORTUNATI, L., U. MAMMINI, D. LARI, R. CIARDELLI, F. SERENA, and A. ABELLA. 2001. Interactive viewer of information on catch, effort, fleet and fishing grounds acquired through interviews at the landings. In: Proceedings of the. First International Symposium on GIS in Fishery Science. T. Nishida, C. E. Hollingworth and P. Kailola (eds.). Seattle, WA, 2-4 March 1999. Fishery GIS Research Group, Kawagoe, Saitama, Japan, pp. 90-118.

JARDAS, I. 1979. Morphological, biological and ecological characteristics of the lesser spotted dogfish, Scyliorhinus canicula (L., 1758). Population in the Adriatic Sea. Reports, 4(2-3), $104 \mathrm{p}$.
MANCUSI, C., B. CATALANO, S. CLÒ, M. DALÚ, F. SERENA, and M. VACCHI. (In press). Tag and release of Raja asterias juveniles in the South Ligurian Sea: preliminary results and future perspectives. Presented at the $6^{\text {th }}$ Annual Scientific Meeting of the European Elasmobranch Association 6-8 Sept. 2002, Cardiff, UK.

MUSICK, A. J. 1999. Criteria to Define Extinction Risk in Marine Fishes. The American Fisheries Society initiative. Fisheries, 24(12): 6-14.

MUSICK, A. J., G. BURGESS, G. CAILLIET, M. CAMHI, and S. FORDHAM. 2000. Management of Sharks and Their Relatives (Elasmobranchii). AFS Policy Statement, Fishery, 25(3): 9-13.

RELINI, G., and C. PICCINETTI. 1996. Ten years of trawl surveys in Italian Seas (1985-1995). FAO Fish. Rep., 533(Suppl.): 21-41.

RELINI, G., J. BERTRAND, and A. ZAMBONI. 1999. SYNDEM Synthesis of the knowledge on Bottom Fishery Resources in Central Mediterranean (Italy and Corsica). Biol. Mar. Medit., 6(Suppl.): 1-869.

SÀNCHEZ, P. (in press). The impacts of bottom trawling in the Mediterranean. WWF Workshops on Ecosystem Approach and Integrating Fisheries and Conservation Frameworks.

SERENA, F., and J.A. ABELLA. 1999. Sheets of the species, Part two 58-98. In: RELINI, G., J. BERTRAND, and A. ZAMBONI. SYNDEM Synthesis of the knowledge on Bottom Fishery Resources in Central Mediterranean (Italy and Corsica). Biol. Mar. Medit., 6(Suppl.): 1-869.

STEVENS, J. D., R. BONFIL, N. K. DULVY, and P-A. WALKER. 2000. The effects of fishing on sharks, rays, and chimaeras (chondrichthyans), and implication for marine ecosystems. ICES J. Mar. Sci., 57: 476-494.

TORTONESE, E. 1956 Fauna d'Italia. Leptocardia-Ciclostomata-Selachii. Ed. Calderoni, Bologna, 334 p.

UNGARO, N., G. MARANO, and R. MARSAN. 1994. Galeus melastomus Rafinesque, 1810 (Selachii, Scyliorhinidae). Distribuzione e biologia sui fondi batiali del basso Adriatico. Accademia Pugliese delle Scienze, Atti e Relazioni, 49: 195-207.

VACCHI, M., V. BIAGI, R. PAJETTA, R. FIORDIPONTI, F. SERENA, and G. NOTARBARTOLO DI SCIARA. 2000. Elasmobranch catches by tuna trap of Baratti (Northern Tyrrhenian Sea) from 1898 to 1922 . Livorno (Italy), 2000. M. Vacchi, G. La Mesa, F. Serena and B. Séret (eds.), ICRAM, ARPAT and SFI. Europ. Elasm. Assoc. Meet. Proc., 4: 177-183.

WALKER, P. A., and J. R. G.HISLOP. 1998. Sensitive skates or resilient rays? Spatial and temporal shifts in ray species composition in the central and north-western North Sea between 1930 and the present day. ICES J. Mar. Sci., 55: 392-402. 